\title{
Research Article: Foxtail millet (Sataria italica) instant puliogare mix
}

Article Chronicle : Received :

10.07.2017;

Accepted :

23.07.2017

KEY WoRds:

Foxtail millet,

Packaging materials, Shelf- life

\section{SATISHKUMAR, FARHEENTAJ, S. SUBRAMANYA AND GEETHAK}

SUMMARY : Foxtail millet (Sataria italica) is an annual warm season grass which was used to prepare some foods in some parts of Karnataka. Foxtail millet is highly nutritious, non-glutinous and not acid forming foods. Hence, they are soothing and easy to digest. The present study was focused on development of ready-to-cook puliogare mix using foxtail millet rice. The proximate composition of the puliogare mix was found to contain $13.50(\mathrm{~g}), 4.50(\mathrm{~g}), 7.71(\mathrm{~g}), 68.22(\mathrm{~g})$ and $365(\mathrm{Kcal})$ and $8.20(\mathrm{mg})$ of protein, fat, crude fibre, carbohydrates, energy and iron, respectively. The product was stored in three different packaging materials namely, Polyethylene, Polypropylene and Aluminium Laminated Foil pouch for 3 months under ambient condition for shelf-life study. Ready-to-cook puliogare mix was subjected to sensory evaluation and nutritional analysis. The results of the study revealed that ready-to-cook puliogare mix packed in aluminium laminated foil pouch showed highest score with respect to appearance (7.2), colour (7.0), aroma (6.4), taste (7.0) and overall acceptability (7.0) compared to puliogare mix stored in other two packaging materials.

How to cite this article : Satishkumar, Farheentaj, Subramanya, S. and Geethak (2017). Foxtail millet (Sataria italica) instant puliogare mix. Agric. Update, 12(TECHSEAR-2) : 343-346; DOI: 10.15740/HAS/AU/12. TECHSEAR (2)2017/343-346.
Author for correspondence :

\section{SATISHKUMAR}

Centre of Excellence on Small Millets,

University of

Agricultural Sciences, G.K.V.K., BENGALURU (KARNATAKA) INDIA Email : satishkumarn 0506@gmail.com

See end of the article for authors' affiliations 